\title{
Pengaruh Suhu Fusi Terhadap Pembentukan Zeolit A Dari Abu Layang Batubara Paiton: Kapasitas Penukar Kation $\left(\mathrm{Ca}^{2+}\right)$
}

Tri Wahyuni, Suprapto, Didik Prasetyoko

\author{
Jurusan Kimia, Fakultas Matematika dan Ilmu Pengetahuan Alam, Institut Teknologi Sepuluh Nopember \\ (ITS), Surabaya, Indonesia \\ Email: didikp@chem.its.ac.id
}

\begin{abstract}
Abstrak--Pada penelitian ini, zeolit A berhasil disintesis dari abu layang batubara Paiton melalui metode pemisahan magnetik untuk memisahkan besi (Fe) dilanjutkan dengan fusi menggunakan $\mathrm{NaOH}$ untuk mengaktivasi Si dan $\mathrm{Al}$, ekstraksi Si dan Al dan tahap akhir adalah kristalisasi. Varisasi suhu fusi dilakukan pada range 400, 450, 500, 550, 600 dan $650{ }^{\circ} \mathrm{C}$. Rasio gel yang digunakan yaitu $\mathrm{Si} / \mathrm{Al}=1,64$. Kristalisasi dilakukan pada suhu $100{ }^{\circ} \mathrm{C}$ selama 3 jam. Padatan yang terbentuk dikarakterisasi menggunakan $X$-ray diffraction (XRD), spektroskopi infra merah (FTIR) dan penentuan kapasitas penukar kation $\left(\mathrm{Ca}^{2+}\right)$. Berdasarkan hasil karakterisasi XRD dan FTIR menunjukkan bahwa zeolit A murni terbentuk pada suhu fusi $450{ }^{\circ} \mathrm{C}$ adapun pada suhu fusi 400 , 500, $550{ }^{\circ} \mathrm{C}$ terbentuk zeolit A dan faujasit dan pada suhu $600,650{ }^{\circ} \mathrm{C}$ terbentuk fasa amorf. Berdasarkan penentuan kapasitas penukar kation (CBC) didapatkan hasil terbesar pada produk hasil sintesis di suhu fusi $450{ }^{\circ} \mathrm{C}$ sebesar $448,19 \mathrm{meq} / 100 \mathrm{~g}$.
\end{abstract}

Kata kunci : abu layang batubara, suhu fusi, zeolit A, CBC

\section{Pendahuluan}

Penggunaan batubara sebagai sumber energi akan menghasilkan abu berupa abu layang (fly ash) dan abu dasar (bottom ash). Kandungan abu layang sekitar $84 \%$ dari total abu yang dihasilkan. Pemanfaatan abu layang secara langsung diantaranya sebagai material konstruksi, semen. Sekalipun demikian, lebih dari 500 juta ton/tahun abu layang yang dihasilkan, hanya sekitar $20 \%$ yang digunakan (Niran dkk., 2001). Hal ini mengindikasikan perlu dilakukan pemanfaatan abu layang batubara.

Salah satu aplikasi abu layang batubara yaitu digunakan sebagai material utama untuk mensintesis zeolit. Komponen utama yang terdapat di batubara antara lain kuarsa $\left(\mathrm{SiO}_{2}, 20\right.$ $70 \%$ ), alumina $\left(\mathrm{Al}_{2} \mathrm{O}_{3}, 10-40 \%\right)$ (Moreno dkk., 2001). Komponen tersebut merupakan material utama yang digunakan untuk mensintesis zeolit. Beberapa peneliti telah mensintesis zeolit menggunakan metode yang berbeda diantaranya, hidrotermal secara langsung (Murayama dkk., 2002; Querol dkk., 2001; Himura dkk., 2001;
Tomasz dkk., 2008), sintesis hidrotermal dari abu layang batubara dan alkali yang telah difusi terlebih dahulu (Rayalu dkk., 2001), sintesis hidrotermal menggunakan ekstrak silika dari abu layang (Moreno dkk., 2002).

Salah satu jenis zeolit yang dapat disintesis dari abu layang batubara adalah zeolit A. Zeolit A tersusun dari silikat dan aluminat dalam jumlah yang sama dan membentuk struktur tetrahedral $\mathrm{SiO}_{4}$. Framework aluminosilikat dari zeolit A terdiri dari struktur kubik yang sederhana dengan delapan tetrahedral dan sebuah octahedron dengan 24 tetrahedral sebagai sangkar (Oonkhand dan Mullins, 2004). Substitusi atom $\mathrm{Si}^{4+}$ dengan $\mathrm{Al}^{3+}$ pada framework menjadi seimbang maka diperlukan penambahan kation untuk menyeimbangkan muatan negatif (Zhadnov, 1971).

Sintesis zeolit A dipengaruhi beberapa faktor antara lain pembentukan fasa metastabil, pelarutan fasa gel, pembentukan inti serta pertumbuhan fasa zeolit. Mekanisme sintesis zeolit A yaitu aktivasi $\mathrm{SiO}_{4}$ dan $\mathrm{Al}_{2} \mathrm{O}_{3}$ yang terdapat pada abu layang batubara dengan menggunakan alkali sebagai 
agen pengaktivasi. Aktivasi dilakukan pada suhu yang tinggi untuk melarutkan silika dan alumina. Pelarutan tergantung pada suhu fusi, media alkali yang digunakan dan konsentrasi alkali yang digunakan. Kelarutan $\mathrm{SiO}_{4}$ dan $\mathrm{Al}_{2} \mathrm{O}_{3}$ akan lebih cepat dengan bertambahnya konsentrasi alkali (Inada ddk., 2004). Oleh karena itu, pelarutan silika dan alumina merupakan tahapan penting dalam sintesis zeolit A dari abu layang batubara.

Pada penelitian ini, sintesis zeolit A dari abu layang batubara menggunakan metode fusi. Abu layang dan $\mathrm{NaOH}$ difusi untuk mengaktivasi silika dan alumina. Salah satu faktor yang mempengaruhi aktivasi silika dan alumina di abu layang batubara adalah suhu fusi. Oleh karena itu, pada penelitian ini difokuskan pada pengaruh suhu fusi $\left(400-650{ }^{\circ} \mathrm{C}\right)$. Sintesis dilakukan dengan rasio $\mathrm{NaOH} /$ abu layang $=1,4 ;$ rasio $\mathrm{SiO}_{2} / \mathrm{Al}_{2} \mathrm{O}_{3}=$ 1,64; waktu fusi 2 jam; hidrotermal selama 3 jam pada suhu $100{ }^{\circ} \mathrm{C}$. Adapun produk yang dihasilkan diaplikasikan senagai penukar kation (CBC).

\section{Metodologi}

\subsection{Bahan}

Zeolit A disintesis menggunakan abu layang batubara dari Paiton-Probolinggo dengan komposisi (wt\%) (wt\%) $\quad \mathrm{Al}_{2} \mathrm{O}_{3} \quad(9,8 \%), \quad \mathrm{SiO}_{2}$ $(33,5 \%), \quad \mathrm{K}_{2} \mathrm{O}(0,97 \%), \quad \mathrm{CaO}(21,4 \%), \quad \mathrm{TiO}_{2}$ $(1,01 \%), \mathrm{Fe}_{2} \mathrm{O}_{3}(30,18 \%), \mathrm{CuO}(0,31 \%), \mathrm{SO}_{3}$ $(1,1 \%), \quad \mathrm{In}_{2} \mathrm{O}_{3}(0,6 \%), \mathrm{BaO}(0,33 \%) ; \mathrm{NaOH}$ (sodium hidroksida, pelet, Applichem, >99,5\%); sodium aluminat anhidrat $\left(\mathrm{NaAlO}_{2}\right.$, sigma Aldrich, $\mathrm{Al}_{2} \mathrm{O}_{3}$ 50-56\%, $\mathrm{Na}_{2} \mathrm{O}$ 40-45\%), $\mathrm{CaCl}_{2} \cdot 2 \mathrm{H}_{2} \mathrm{O}$, aquades.

\subsection{Reduksi $\mathrm{Fe}_{2} \mathrm{O}_{3}$}

Metode pemisahan magnetik digunakan untuk mereduksi $\mathrm{Fe}_{2} \mathrm{O}_{3} .50$ gram abu layang batubara dimasukkan dalam bejana berisi air $1 \mathrm{~L}$ diaduk menggunakan pemisah magnetik sampai besi terpisah dari abu layang batubara.

\subsection{Sintesis Zeolit A}

Rasio NaOH/abu layang (hasil pemisahan magnetik) $=1,4$ difusi selama 2 jam dengan variasi suhu fusi $400-650{ }^{\circ} \mathrm{C}$. Massa fusi didinginkan, ditambah dengan aquades seabnyak $127,5 \mathrm{~mL}$ dan diaduk selama 24 jam pada suhu ruangan, difiltrasi. Filtrat dikarakterisasi ICP-AES untuk mengetahui konsentrasi $\mathrm{Si}, \mathrm{Al}$, Na yang terekstrak. Filtrat tersebut digunakan untuk sintesis zeolit A dengan penambahan sejumlah Na-aluminat. Penambahan Na-aluminat disesuaikan dengan komposisi rasio yang ditentukan $\mathrm{SiO}_{2} / \mathrm{Al}_{2} \mathrm{O}_{3}=1,64$. Larutan $\mathrm{Na}$ aluminat dibuat dengan melarutkan sejumlah $\mathrm{Na}$ aluminat ke dalam 22,5 mL larutan $\mathrm{NaOH} 1,67 \mathrm{M}$, diaduk selama 15 menit. Selanjutnya larutan Naaluminat dicampur dengan filtrat diaduk selama 30 menit, dimasukkan ke autoclave, hidrotermal selama 3 jam pada suhu $100{ }^{\circ} \mathrm{C}$. Larutan gel didinginkan, difiltrasi dan padatan yang terbentuk dicuci dengan aquades hingga $\mathrm{pH}$ 10-11 dan dikeringkan selama 24 jam pada suhu $100{ }^{\circ} \mathrm{C}$. Padatan dikarakterisasi menggunakan XRD dan FT-IR.

\subsection{Penentuan Kapasitas Penukar Kation (CBC)}

Larutan $\mathrm{Ca}$ awal dibuat dengan melarutkan 0,67 gram $\mathrm{CaCl}_{2} \cdot 2 \mathrm{H}_{2} \mathrm{O}$ dengan $50 \mathrm{~mL}$ larutan $\mathrm{NaOH}$ $0,02 \mathrm{M}$. Larutan Ca diencerkan sampai volume 1 L. Selanjutnya diambil $250 \mathrm{~mL}$ ditambah dengan 0,25 gram zeolit A dari hasil sintesis diaduk selama 15 menit. Campuran disaring dengan kertas saring, filtrat dikarakterisasi menggunakan ICP untuk menentukan kapasitas pengikatan kation (CBC). CBC dtentukan dengan menngunakan persamaan sebagai berikut:

$C B C=\frac{C \cdot \text { awal }- \text { C.akhir }(\mathrm{mg} / \mathrm{L}) \times \text { eq } \times \mathrm{V} \cdot \text { larutan }(L)}{A r(g / \text { mol }) \times \text { massa zeolit }(g)} \times 100$

dengan:

$\begin{array}{lll}\mathrm{CBC} & = & \text { kapasitas penukar kation } \\ (\mathrm{meq} / 100 \mathrm{~g}) & \\ \text { C.awal } & =\text { konsentrasi larutan Ca awal }(\mathrm{ppm}) \\ \text { C.akhir } & =\text { konsentrasi larutan Ca akhir }(\mathrm{ppm}) \\ \mathrm{Eq} & =\text { equivalen muatan }(2) \\ \text { V.larutan } & =\text { volume larutan } \mathrm{Ca}(0,25 \mathrm{~L}) \\ 100 & =\text { faktor kali massa padatan }(100 \mathrm{~g}) \\ \text { Ar } & =\text { massa atom relative } \mathrm{Ca}(40 \mathrm{~g} / \mathrm{mol})\end{array}$

Massa zeolite $=0,25 \mathrm{~g}$

\section{Hasil dan Pembahasan}

Abu layang batubara Paiton digunakan sebagai material utama untuk sintesis zeolit A. Abu layang batubara dikarakterisasi XRF untuk mengetahui komposisi kimianya. Hasil karakterisasi XRF ditunjukkan pada gambar. Berdasarkan Tabel 1. Terlihat bahwa komposisi dominan yang terdapat pada abu layang batubara antara lain $\mathrm{SiO}_{2}$ (33,50\%), $\mathrm{Al}_{2} \mathrm{O}_{3}(9,8 \%), \mathrm{Fe}_{2} \mathrm{O}_{3}(30,18 \%), \mathrm{CaO}$ $(21,40 \%)$. Hal ini juga dilaporkan oleh Somerset 
dkk., (2007) bahwa komponen utama pada abu layang batubara untuk sintesis zeolit adalah aluminosilikat, mullit $\left(\mathrm{Al}_{6} \mathrm{Si}_{2} \mathrm{O}_{13}\right)$ dan kuarsa $\left(\mathrm{SiO}_{2}\right)$. Berdasarkan hasil tersebut menunjukkan bahwa komposisi $\mathrm{SiO}_{2}$ dan $\mathrm{Al}_{2} \mathrm{O}_{3}$ sesuai sebagai material untuk sintesis zeolit A. Adapun komposisi besi yang cukup banyak maka dilakukan penghilangan besi menggunakan metode pemisahan magnetik, selanjutnya dikarakterisasi menggunakan XRF. Hasil ini ditunjukkan pada Tabel 2. Berdasarkan Tabel 2. terlihat bahwa pemisahan magnetik tidak mempengaruhi secara signikan terhadap reduksi besi karena besi yang tereduksi hanya sebesar $17 \%$.

Hasil karakterisasi XRD abu layang batubara dan hasil dari pemisahan magnetik, ditunjukkan pada Gambar 1. Berdasarkan Gambar 1. terlihat bahwa fasa yang terdapat pada abu layang batu bara yaitu kuarsa $\left(\mathrm{SiO}_{2}\right)$, mullit $\left(\mathrm{Al}_{2} \mathrm{O}_{3}\right)$ dan kalsit $(\mathrm{CaO})$. Hasil yang sama ditunjukkan pada abu layang pemisahan magnetik. Adapun hasil karakterisasi FTIR abu layang batubara dan abu layang batubara pemisahan magnetik ditunjukkan pada Gambar 2. Berdasarkan gambar tersebut menunjukkan bahwa hasil karakterisasi FTIR pada abu layang batubara dan abu layang pemisahan magnetik menunjukkan hasil yang serupa. Pada bilangan gelombang $454 \mathrm{~cm}^{-1}$ menunjukkan vibrasi tekuk (Si-O-Si), $772 \mathrm{~cm}^{-1}$ merupakan vibrasi ulur simetri (Si-O-Si) menunjukkan kuarsa (Kister dan Dou, 1986), 986 dan $990 \mathrm{~cm}^{-1}$ merupakan vibrasi ulur asimetri (SiO-Si dan Si-O-Al) menunjukkan mullit (Lee dan Deventer, 2002). Hasil ini memperkuat hasil karakterisasi XRD dan XRF bahwa komponen utama di abu layang batubara adalah kuarsa dan mullit.
Reaksi fusi dengan mencampurkan abu layang batubara hasil pemisahan magnetik dengan $\mathrm{NaOH}$ pada crusibel stainless steel dengan perbandingan massa $\mathrm{NaOH} / \mathrm{abu}$ layang sebesar 1,4 (Sudarno, 2008) selama 2 jam dengan variasi suhu fusi 400 $650{ }^{\circ} \mathrm{C}$. Tujuan reaksi fusi alkali adalah untuk mengaktivasi $\mathrm{SiO}_{2}$ dan $\mathrm{Al}_{2} \mathrm{O}_{3}$ pada abu layang batubara sehingga diharapkan $\mathrm{SiO}_{2}$ dan $\mathrm{Al}_{2} \mathrm{O}_{3}$ berubah struktur menjadi garam alkali yang mudah larut dalam air (Ojka dkk., 2004). Oleh karena itu, reaksi fusi sangat efektif untuk mengekstrak Si dan Al pada abu layang batubara.

Hasil karakterisasi XRD massa fusi pada suhu fusi 400-600 ${ }^{\circ} \mathrm{C}$ ditunjukkan ada Gambar 1. Berdasarkan hasil karakterisasi tersebut menunjukkan bahwa pada suhu fusi $400{ }^{\circ} \mathrm{C}$ fasa yang teramati antara lain kuarsa, mullit, natrium silikat dan natrium aluminosilikat. Adanya kuarsa dan mullit yang merupakan fasa kristal akan memperkecil kelarutan. Adapun fasa yang teramati pada suhu fusi $450-600{ }^{\circ} \mathrm{C}$ yaitu natrium silikat dan natrium aluminosilikat. Leburan massa fusi dicampur dengan aquades di botol polipropilen dan dilakukan pengadukan selama 24 jam pada suhu ruangan. Selanjutnya disaring maka didapatkan filtrat dan residu. Filtrat dikarakterisasi dengan ICP untuk menentukan $\mathrm{Si}$, $\mathrm{Al}$ dan $\mathrm{Na}$ yang larut. Hasil karakterisasi ICP ditunjukkan pada Tabel 3. Berdasarkan Tabel 3. terlihat bahwa pada suhu fusi $400{ }^{\circ} \mathrm{C}$ kelarutan $\mathrm{Si}$, $\mathrm{Al}, \mathrm{Na}$ menunjukkan hasil terendah. Hal ini berkaitan dengan hasil karaktersisasi XRD pada massa fusi suhu tersebut menunjukkan bahwa masih terdapat kuarsa dan mullit yang tidak larut di air. Adapun kelarutan $\mathrm{Si}, \mathrm{Al}, \mathrm{Na}$ terbanyak terdapat pada suhu fusi $450{ }^{\circ} \mathrm{C}$ dibandingkan dengan suhu fusi $500-600{ }^{\circ} \mathrm{C}$.

Tabel 1. Komposisi kimia abu layang

batubara Paiton berdasarkan hasil karakterisasi XRF

\begin{tabular}{cccccccc}
\hline Senyawa & $\%$ Berat & Senyawa & \% Berat & Senyawa & \% Berat & Senyawa & \% Berat \\
\hline $\mathrm{SiO}_{2}$ & $\mathbf{3 3 , 5 0}$ & $\mathrm{K}_{2} \mathrm{O}$ & $\mathbf{0 , 9 7}$ & $\mathrm{BaO}$ & $\mathbf{0 , 3 3}$ & $\mathrm{ZnO}$ & $\mathbf{0 , 0 2}$ \\
$\mathrm{Al}_{2} \mathrm{O}_{3}$ & $\mathbf{9 , 8 0}$ & $\mathrm{SO}_{3}$ & $\mathbf{1 , 1 0}$ & $\mathrm{MnO}$ & $\mathbf{0 , 2 3}$ & $\mathrm{V}_{2} \mathrm{O}_{5}$ & $\mathbf{0 , 0 3 8}$ \\
$\mathrm{Fe}_{2} \mathrm{O}_{3}$ & $\mathbf{3 0 , 1 8}$ & $\mathrm{TiO}_{2}$ & $\mathbf{1 , 0 1}$ & $\mathrm{HgO}$ & $\mathbf{0 , 0 5}$ & $\mathrm{Cr}_{2} \mathrm{O}_{3}$ & $\mathbf{0 , 0 7 7}$ \\
$\mathrm{CaO}$ & 21,40 & $\mathrm{In}_{2} \mathrm{O}_{3}$ & $\mathbf{0 , 6 0}$ & $\mathrm{CuO}$ & $\mathbf{0 , 0 4}$ & $\mathrm{Hg}$ & $\mathbf{0 , 0 5}$ \\
\hline
\end{tabular}


Tabel 2. Perbandingan komposisi abu layang batubara awal dengan hasil pemisahan magnetik berdasarkan karakterissi XRF

\begin{tabular}{ccc}
\hline Senyawa & \% Berat abu layang awal & \% Berat abu layang pemisahan magnetik \\
\hline $\mathrm{SiO}_{2}$ & 33,50 & 36,60 \\
$\mathrm{Al}_{2} \mathrm{O}_{3}$ & 9,80 & 11,00 \\
$\mathrm{Fe}_{2} \mathrm{O}_{3}$ & 30,18 & 25,57 \\
$\mathrm{CaO}$ & 21,40 & 22,10 \\
\hline
\end{tabular}

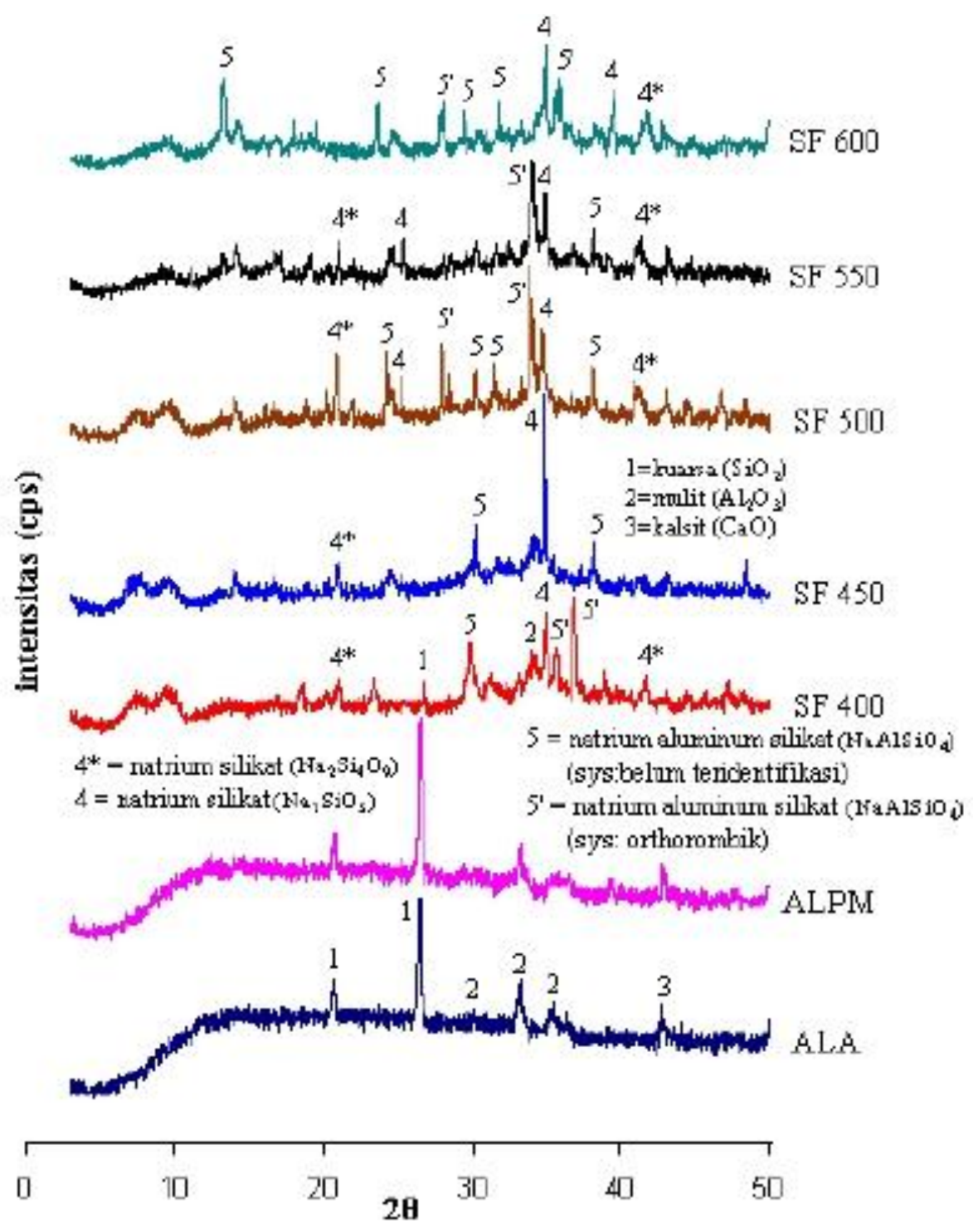

Gambar 1, Hasil karakterisasi XRD; ALA (abu layang awal), ALPM (abu layang pemisahan magnetik), $\mathrm{SF}$ (suhu fusi: $400,450,500,550,600{ }^{\circ} \mathrm{C}$ ). 


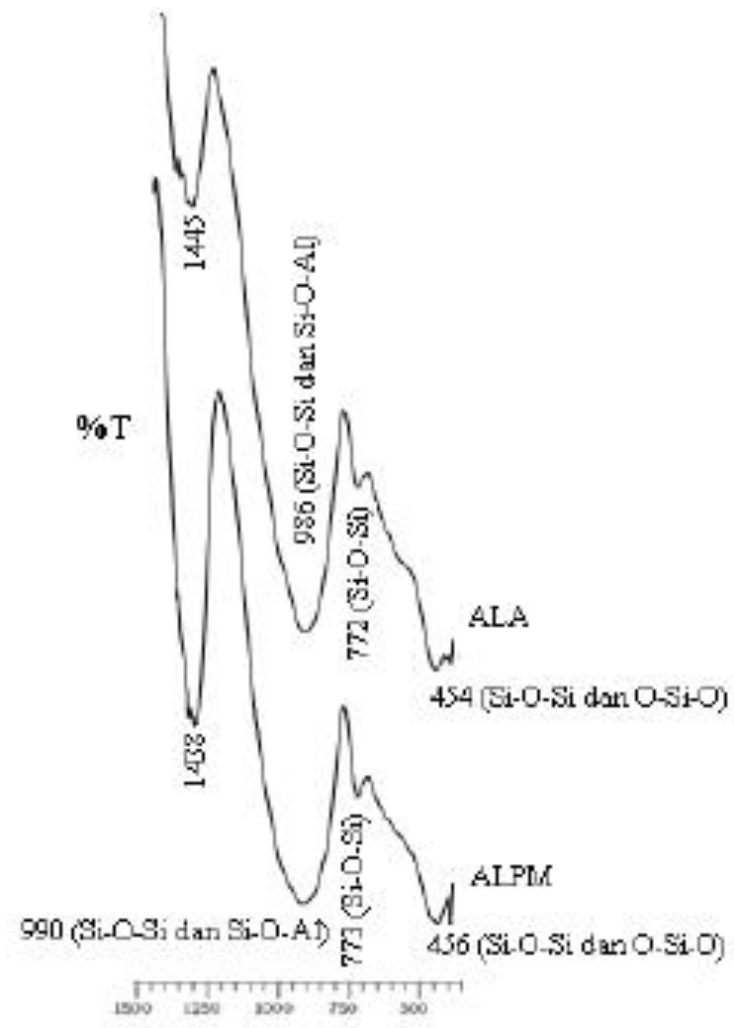

Gambar 2. Spektra FTIR untuk abu layang awal (ALA) dan abu layang pemisahan magnetik (ALPM)

Tabel 2. Perbandingan komposisi abu layang batubara awal dengan hasil pemisahan magnetic berdasarkan karakterissi XRF

\begin{tabular}{ccc}
\hline Senyawa & \% Berat abu layang awal & \% Berat abu layang pemisahan magnetik \\
\hline $\mathrm{SiO}_{\mathbf{2}}$ & 33,50 & 36,60 \\
$\mathrm{Al}_{2} \mathbf{O}_{3}$ & 9,80 & 11,00 \\
$\mathbf{F e}_{2} \mathbf{O}_{3}$ & 30,18 & 25,57 \\
$\mathbf{C a O}$ & 21,40 & 22,10 \\
\hline
\end{tabular}

Tabel 3. Massa fusi yang tereduksi dan konsentrasi $\mathrm{Si}$, Al, Na dari filtrat berdasarkan karakterisasi ICP-spektrometer

\begin{tabular}{|c|c|c|c|c|c|}
\hline \multirow[t]{2}{*}{ SF Sampel } & \multirow[t]{2}{*}{$\%$ MF tereduksi } & \multirow[t]{2}{*}{ Fase } & \multicolumn{3}{|c|}{ Konsentrasi filtrat (ppm) } \\
\hline & & & $\mathbf{S i}$ & Al & $\mathbf{N a}$ \\
\hline $400{ }^{\circ} \mathrm{C}$ & 11,36 & $4,4^{*}, 5,5^{\prime}, \mathrm{Q}, \mathrm{M}$ & 940 & 4600 & 49572 \\
\hline $450{ }^{\circ} \mathrm{C}$ & 9,39 & $4,4^{*}, 5$ & 3139 & 21989 & 182127 \\
\hline $500{ }^{\circ} \mathrm{C}$ & 9,58 & $4,4^{*}, 5,5$ & 1855 & 11060 & 78179 \\
\hline $550{ }^{\circ} \mathrm{C}$ & 9,53 & $4,4^{*}, 5,5$ & 1807 & 12260 & 78821 \\
\hline $600{ }^{\circ} \mathrm{C}$ & 9,86 & $4 *, 5$ & 1445 & 9394 & 76407 \\
\hline $650{ }^{\circ} \mathrm{C}$ & 9,47 & - & 1489 & 9068 & 61381 \\
\hline
\end{tabular}

$\mathrm{SF}=$ suhu fusi, $\mathrm{MF}=$ massa fusi, $4\left(\mathrm{Na}_{2} \mathrm{SiO}_{3}\right), 4^{*}\left(\mathrm{Na}_{2} \mathrm{Si}_{4} \mathrm{O}_{9}\right), 5\left(\mathrm{NaAlSiO}_{4}\right), 5^{\prime}\left(\mathrm{NaAlSiO}_{4}\right.$, sys:orthorombik $), \mathrm{Q}=$ kuarsa $\left(\mathrm{SiO}_{2}\right), \mathrm{M}=$ mullit $\left(\mathrm{Al}_{2} \mathrm{O}_{3}\right)$ 
Suhu fusi $450{ }^{\circ} \mathrm{C}$ dengan kelarutan $\mathrm{Si}, \mathrm{Al}, \mathrm{Na}$ terbanyak digunakan sebagai acuan untuk mengetahui pengaruh waktu kristalisasi terhadap sintesis zeolit A. Filtrat hasil pelarutan massa fusi pada suhu fusi $450{ }^{\circ} \mathrm{C}$ ditambah dengan larutan $\mathrm{NaAlO}_{2}-\mathrm{NaOH}$ untuk menyesuaikan rasio $\mathrm{SiO}_{2} / \mathrm{Al}_{2} \mathrm{O}_{3}$ yang ditentukan yaitu sebesar 1,64 (mengacu pada penelitian Hui dan Chou, 2006). Selanjutnya campuran gel dimasukkan ke autoclave, hidrotermal pada suhu $100{ }^{\circ} \mathrm{C}$ selama 3 , 6, 12 jam. Padatan yang terbentuk dicuci hingga pH 10-11, dkeringkan pada suhu $100{ }^{\circ} \mathrm{C}$ selama 24 jam dan dikarakterisasi XRD. Hasil karakterisasi XRD untuk padatan hasil sintesis pada waktu kristalisasi 3, 6, 12 jam ditunjukkan pada Gambar 3.

Berdasarkan Gambar 3, terlihat bahwa pola difraksi dari padatan hasil sintesis menunjukkan pola difraksi zeolit A. Adapun pola difraksi yang belum sempurna mengindikasikan bahwa proses pembentukan zeolit pada tahapan pengendapan gel sebagai pembentuk zeolit awal belum terjadi sempurna. Waktu kristalisasi 3 jam memiliki kristalinitas tertinggi dibandingkan waktu kristalisasi 6 dan 12 jam. Hasil ini serupa dengan hasil yang dilaporkan oleh Anuwatta dan
Khummongkol (2008) bahwa waktu kristalisasi 1 jam memiliki kristalinitas lebih rendah dibandingkan waktu kristalisasi 2-3 jam, adapun setelah waktu kristalisasi 5 jam, kristalinitas zeolit A mengalami penurunan. Maka dapat disimpulkan bahwa pada penelitian ini, waktu kristalisasi 3 jam sesuai untuk sintesis zeolit A.

Filtrat dari variasi suhu fusi $400-650{ }^{\circ} \mathrm{C}$ ditambah dengan larutan $\mathrm{NaAlO}_{2}-\mathrm{NaOH}$ mengikuti prosedur diatas yaitu hidrotermal pada suhu $100{ }^{\circ} \mathrm{C}$ selama 3 jam. Pemilihan waktu kristalisasi 3 jam merujuk pada hasil variasi waktu kristalisasi terbaik untuk sintesis zeolit A. Adapun prosedur selanjutnya mengikuti tahapan sebelumnya. Padatan hasil sintesis dikarakterisasi menggunakan XRD dan FTIR. Gambar 4 menunjukkan pola difraksi XRD dari produk hasil sintesis pada $2 \theta=5-50^{\circ}$. Berdasarkan Gambar 4 menunjukkan bahwa puncak difraksi padatan hasil sintesis identik dengan puncak difraksi pada data PDF no.39-0222 yang merupakan pola difraksi dari standar zeolit A. Hasil difraksi XRD tersebut mengindikasikan bahwa zeolit A berhasil disintesis dari abu layang batubara Paiton dengan rasio molar $\mathrm{SiO}_{2} / \mathrm{Al}_{2} \mathrm{O}_{3}=1,64$.

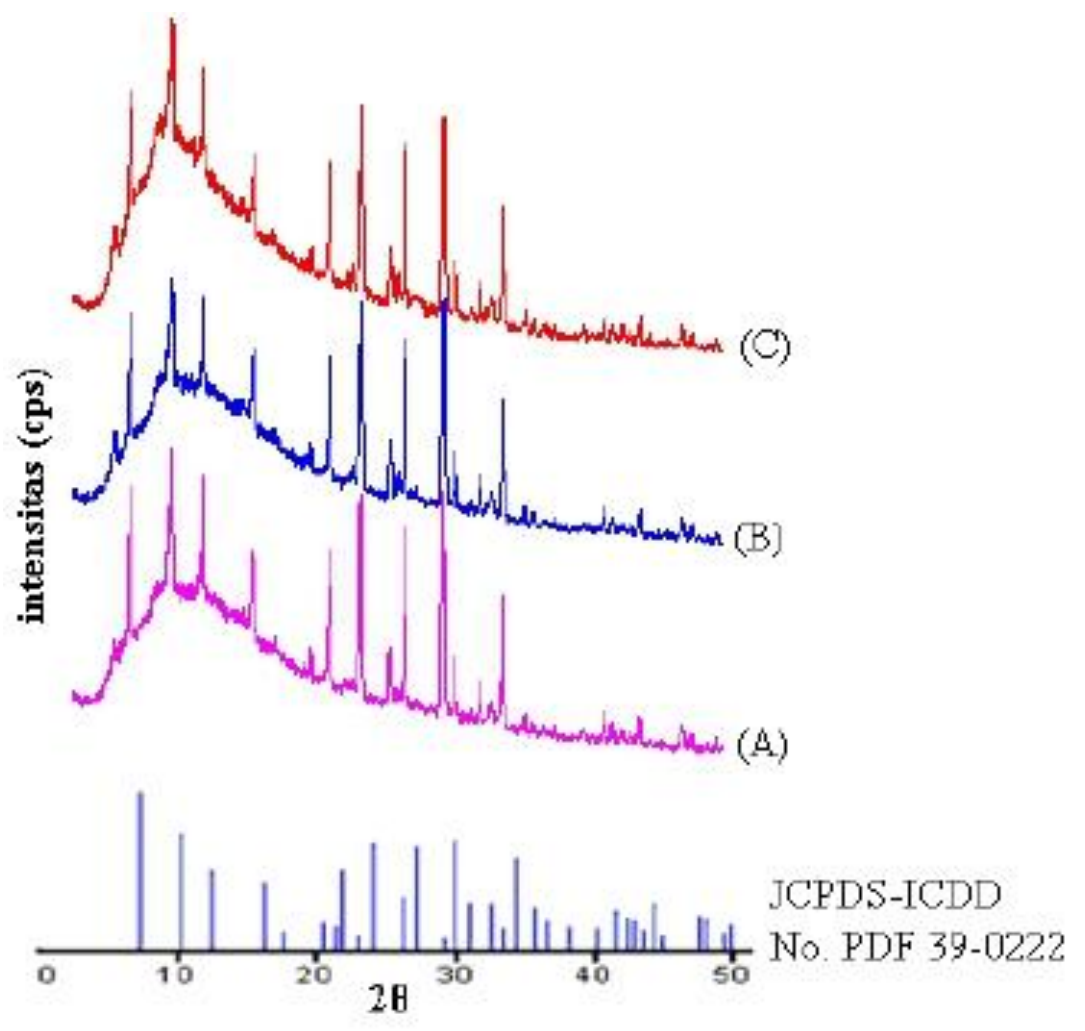

Gambar 3. Hasil karakterisasi XRD dari padatan hasil sintesis berdasarkan variasi waktu kristalisasi ( $A=3$ jam, $B=6$ jam, $C=12$ jam) dibandingkan dengan standar zeolit $A$ 


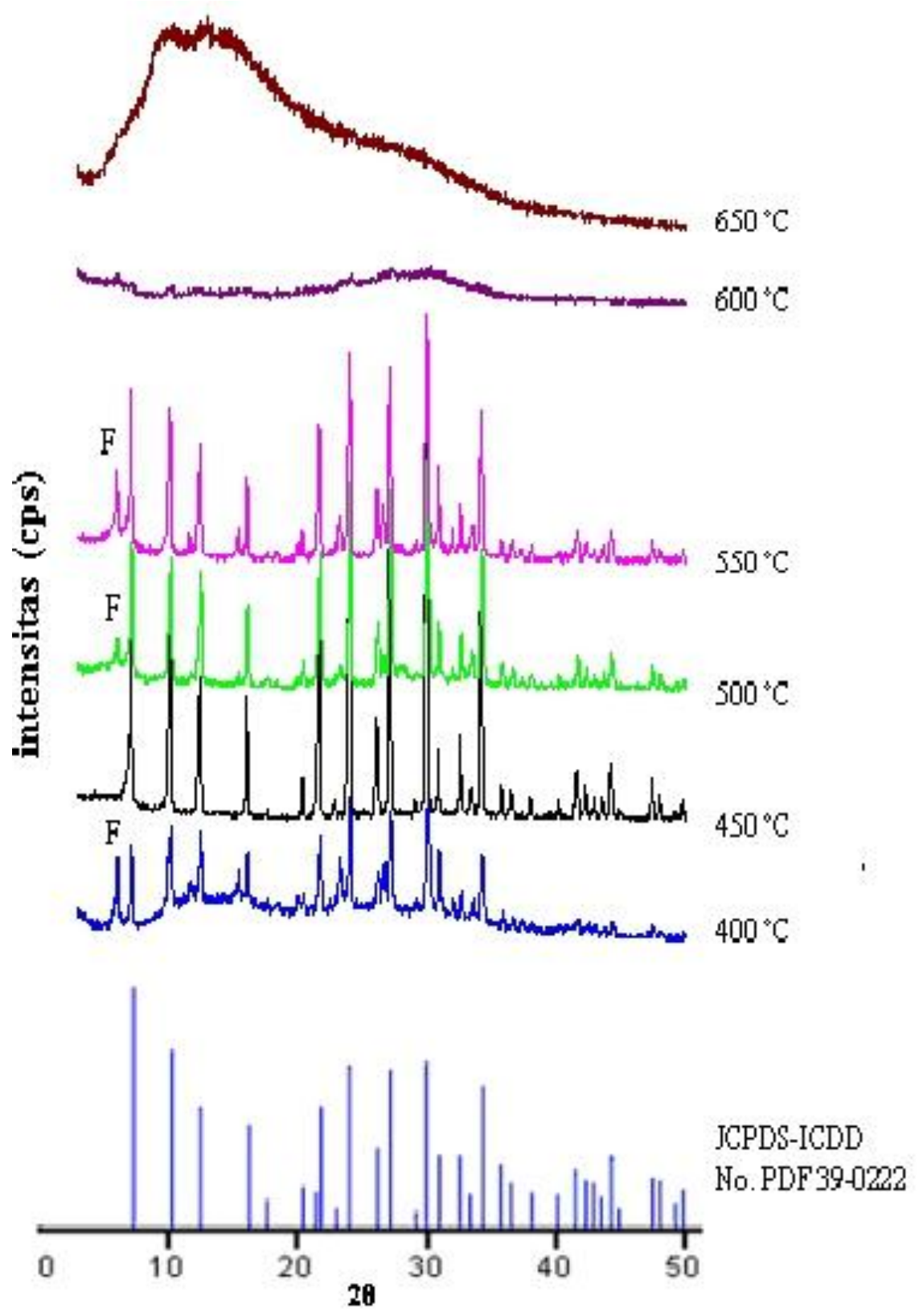

\section{Gambar 4. Hasil karakterisasi XRD dari padatan hasil sintesis berdasarkan variasi suhu fusi (400- $\left.650{ }^{\circ} \mathrm{C}\right)$ dibandingkan standar zeolit A}

Tabel 4. menunjukkan persentase kristalinitas dari padatan yang dihasilkan. Berdasarkan perhitungan persentase kristalinitas terlihat bahwa semakin meningkat suhu fusi, persentase kristalinitas dari padatan hasil sintesis mengalami penurunan. Hasil ini sesuai dengan yang dilaporkan Rayalu dkk., (2000) bahwa semakin bertambahnya suhu fusi maka persentase kristalinitas dari zeolit A semakin berkurang bahkan terbentuk amorf. Demikian juga pada penelitian ini, pada suhu fusi $450{ }^{\circ} \mathrm{C}$ padatan yang dihasilkan merupakan zeolit A dengan kristalinitas tertinggi dan massa yang dihasilkan dalam jumlah yang banyak. Adapun pada suhu fusi $400,500,550{ }^{\circ} \mathrm{C}$ padatan yang dihasilkan merupakan zeolit A dengan impurities berupa faujasit (F) dan pada suhu fusi 600 dan $650{ }^{\circ} \mathrm{C}$ padatan yang dihasilkan adalah amorf. 
Tabel 4. \% Kristalinitas dari padatan hasil sintesis berdasarkan varisasi suhu fusi

\begin{tabular}{|c|c|c|c|c|}
\hline \multirow[t]{2}{*}{ Keterangan } & \multicolumn{4}{|c|}{ Suhu Fusi $\left({ }^{\circ} \mathbf{C}\right)$} \\
\hline & 400 & 450 & 500 & 550 \\
\hline Nilai Intensitas total & 6428 & 1321 & 8518 & 8467 \\
\hline$\%$ Kristalinitas & 48,39 & 100 & 64,14 & 63,37 \\
\hline
\end{tabular}

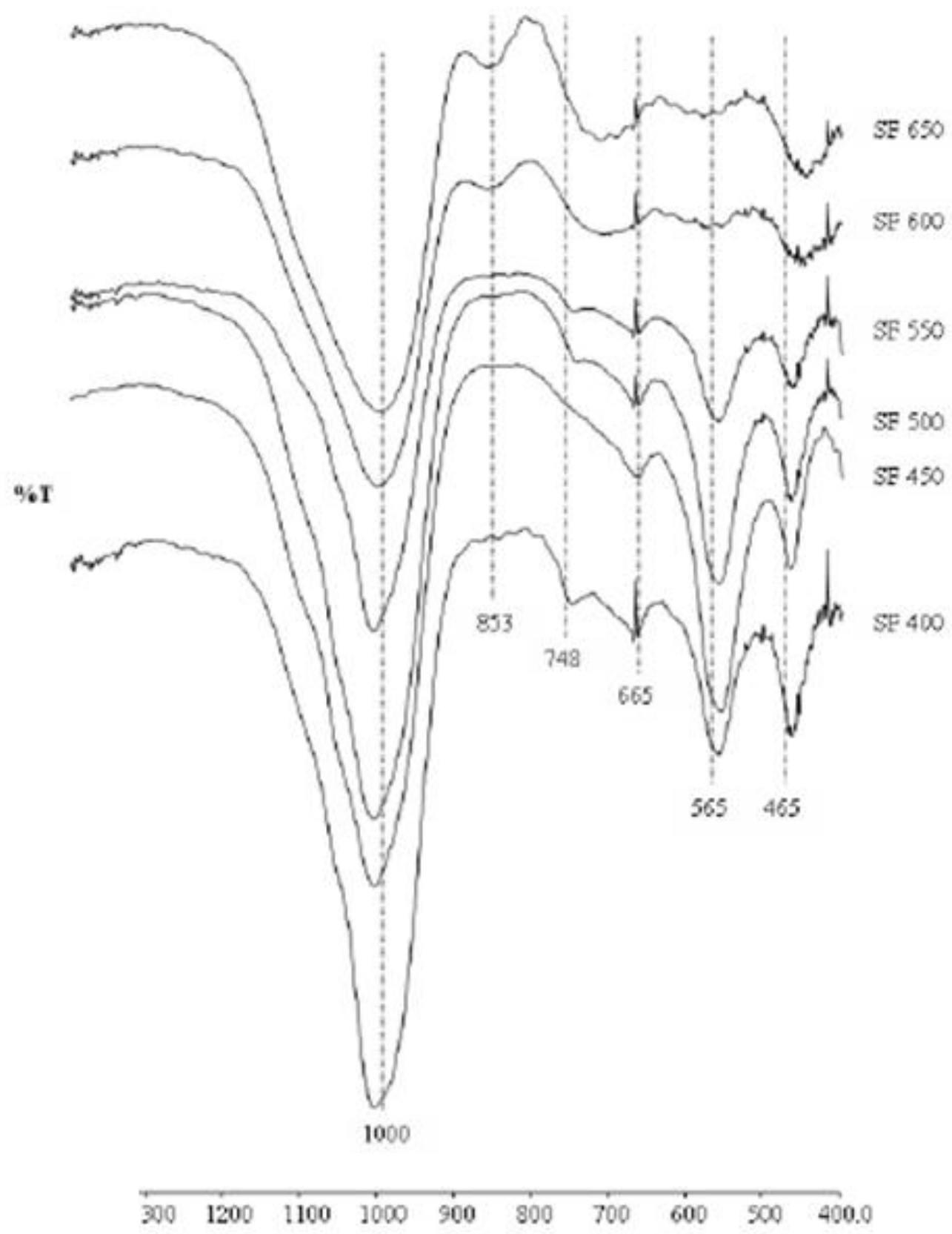

Gambar 5. Spektra FTIR dari padatan hasil sintesis berdasarkan variasi suhu fusi $\left(400-650{ }^{\circ} \mathrm{C}\right)$ 
Tabel 5. Nilai kapasitas penukar kation (CBC) dan massa dari padatan hasil sintesis

\begin{tabular}{ccccccc}
\hline Keterangan & \multicolumn{7}{c}{ Suhu Fusi $\left({ }^{\circ} \mathbf{C}\right)$} \\
\hline & $\mathbf{4 0 0}$ & $\mathbf{4 5 0}$ & $\mathbf{5 0 0}$ & $\mathbf{5 5 0}$ & $\mathbf{6 0 0}$ & $\mathbf{6 5 0}$ \\
\cline { 2 - 7 } CBC (meq/100 g) & 315,26 & 448,19 & 185,15 & 154,66 & 85,92 & 51,69 \\
Massa Padatan $(\mathbf{g})$ & 1,89 & 4,37 & 2,97 & 2,98 & 2,03 & 1,98 \\
\hline
\end{tabular}

Gambar 5. Menunjukkan spektra FTIR dari padatan hasil sintesis. Pada suhu fusi $400-550{ }^{\circ} \mathrm{C}$ menunjukkan spektra FTIR yang identik dengan spektra FTIR dari zeolit A yang dilaporkan oleh Rayalu dkk. (1999). Bilangan gelombang sekitar $466 \mathrm{~cm}^{-1}$ menunjukkan vibrasi tekuk ( $\left.\mathrm{Si}-\mathrm{O}-\mathrm{Si}\right)$, $565 \mathrm{~cm}^{-1}$ menunjukkan cincin ganda empat (D4R), $665 \mathrm{~cm}^{-1}$ menunjukkan vibrasi ulur simetri (Si-O$\mathrm{Al}), 1000 \mathrm{~cm}^{-1}$ menunjukkan vibrasi ulur asimetri (Si-O-Al). Pada suhu fusi 400,500 dan $550{ }^{\circ} \mathrm{C}$ muncul bilangan gelombang sekitar $748 \mathrm{~cm}^{-1}$ yang menunjukkan vibrasi ulur simetri eksternal. Menurut Fotovat dkk. (2008) bahwa pada bilangan sekitar $750 \mathrm{~cm}^{-1}$ mengindikasikan adanya faujasit. Hal ini memperkuat hasil karakterisasi XRD bahwa pada suhu fusi 400, 500 dan $550 \mathrm{~cm}^{-1}$ terdapat faujasit. Adapun pada suhu 600 dan 650 $\mathrm{cm}^{-1}$ terdapat bilangan gelombang pada $993 \mathrm{~cm}^{-1}$ menunjukkan vibrasi ulur asimetri (Si-O-Al) dan $856 \mathrm{~cm}^{-1}$ menunjukkan vibrasi ulur simteri T-O (T $=\mathrm{Si}$ atau $\mathrm{Al}$ ). Sehingga dapat disimpulkan bahwa pada suhu 600 dan $650{ }^{\circ} \mathrm{C}$ tidak terbentuk zeolit A.

Pada penelitian ini, padatan yang dihasilkan diaplikasikan sebagai penukar kation (CBC). Metode penelitian yang dilakukan mengacu pada penelitian yang dilakukan Rayalu dkk. (2001). Hasil penentuan penukar kation (CBC) ditunjukkan pada Tabel 5. Berdasarkan Tabel 5 terlihat bahwa semakin meningkat suhu fusi maka nilai $\mathrm{CBC}$ mengalami penurunan. Nilai CBC sebanding dengan jumlah massa produk yang dihasilkan. Nilai CBC terbesar sebesar 448 meq/100 g dan massa terbanyak sebesar 4,37 $\mathrm{g}$ didapatkan dari padatan hasil sintesis pada suhu fusi $450{ }^{\circ} \mathrm{C}$.

\section{Kesimpulan}

Berdasarkan penelitian yang dilakukan, disimpulkan bahwa zeolit A berhasil disintesis dari abu layang batubara Paiton dengan rasio $\mathrm{NaOH} /$ abu layang $=1,4 ;$ rasio $\mathrm{SiO}_{2} / \mathrm{Al}_{2} \mathrm{O}_{3}=1,64$; waktu fusi $2 \mathrm{jam}$; kristalisasi pada suhu $100{ }^{\circ} \mathrm{C}$. Sintesis zeolit A dipengaruhi oleh suhu fusi dan waktu kristalisasi. Waktu kristalisasi yang relatif singkat sesuai untuk sintesis zeolit A yaitu selama 3 jam. Pengaruh suhu fusi terhadap sintesis zeolit A yaitu semakin meningkat suhu fusi yang digunakan maka jumlah $\mathrm{Si}, \mathrm{Al}$ yang larut semakin berurang. Adapun kristalinitas, massa produk serta nilai penukar kation semakin berkurang seiring dengan meningkatnya suhu fusi. Hasil sintesis zeolit A terbaik didapatkan pada suhu fusi $450{ }^{\circ} \mathrm{C}$ dengan nilai penukar kation sebesar 448 meq/100 g, massa padatan sebesar 4,37 g.

\section{Daftar Pustaka}

[1] Anuwattana, R. dan Khummongkol, P., (2008), "Conventional Hydrothermal Synthesis of Na-A Zeolite from Cupola Slag and Aluminum Sludge", Journal of Hazardaous Materials.

[2] Fotovat, F., Kazemian, H., Kazemeini., (2009), "Synthesis of Na-A and Faujasite Zeolites from High Silicon Fly Ash", Materials Research Bulletin 44, 913-917.

[3] Himura, H., Yokota, K., Akiba, K., Onodera, Y., (2001), "Alkali Hydrothermal Synthesis of Zeolite from Coal Fly Ash and Their Uptake Properties of Cesium Ion", Journal Nuclear Science Technology 38 (9), 766-772.

[4] Hui, K. S., Chao, C. Y. H., (2006), "Pure, Singgle, Phase, Hight Crystalline, Chamfered-Edge Zeolite 4 A Synthesized from Coal Fly Ash for Use a Builder Detergent", Journal Hazardous Materials B 137, 401-409.

[5] Inada, M., Eguchi, Y., Enomoyo, N., Hojo, J., (2004), "Synthesis of Zeolite from Coal Fly Ashes with Different Silica-Alumina Composition", Department of Chemistry and Biochemistry, Japan, Fuel 84, 299-304.

[6] Kister, J. dan Dou, H., (1986), "Global Characterization of The Chemical Constituents of Coal by X-scanner, UV-Fluororesence Spectroscopy and FTIR Spectroscopy", Fuel Processing Technology 12, 19-29.

[7] Lee, W. K. W. dan Deventer Van, J. S. J., (2002), "Structural Reorganisation of Class F Fly Ash in Alkaline Silicate Solutions", Colloids and Surface A : Physicochem. Engineering Aspect 211, 49-66.

[8] Moreno, N., Querol, X., Ayora, C., Alastuey, A., Pereira, C. F., Jurkovicora, M. J., (2001), "Potential Environmental Applications of Pure 
Zeolitic Material Synthesis from Fly Ash", Journal Environment Engineering, 994-1002.

[9] Moreno, N., Querol, X., Plana, F., Andrea, J. M., Nugteren, H., (2002), "Pure Zeolite Synthesis from Silica Extracted from Coal Fly Ash", Journal Chemistry Technology Biotechnology 77 (3), 274-279.

[10] Murayama, N., Yamamoto, H., Shibata, J., (2002), "Mechanism of Zeolie Synthesis from Coal Fly Ash by Alkali Hydrothermal Reaction", International Journal Minerals Process 64 (1), 117.

[11] Niran, J., Blackburn, D., Wilson, M., (2001), "Research and Development for Fly Ash:Opportunity or Alchemy, in: $18^{\text {th }}$ Annual International Pittsburg Coal Conference, Newcastle.

[12] Ojha, K., Pradhsn, N. dan Samanta, A. N., (2004), "Zeolite from Fly Ash: Synthesis and Characterization", Bulletin Materials Science Indian Academy of Sciences 27 (6), 555-564.

[13] Oonkhand, B., dan Mullins, M. E., (2004), "The Effect of Composition on The Growth and Morphology of Zeolite A in Solution", Journal Research Society Vol. 19, No. 6, 1613-1622.

[14] Querol, X., Moreno, N., Umana, J. C., Alastuey A., Hernandez, E., Lopez-Soler, A., Plana, F., (2001), "Synthesis of Zeolites from Coal Fly Ash: An Overview", International Journal of Coal Geology 50, 413-423.
[15] Rayalu, S. S., Udhoji, D. S., Meshram, S. U., Naidu, R. R., Devota, S., (1999), "Estimation of Crystallinity in Fly Ash-Based Zeolite A Using XRD and IR Spectroscopy", Environmental Materials Unit, National Environmental Engineering Research Institute, Nagpur 440020 , India.

[16] Rayalu, S., Meshram, S. U., Hasan, M. Z., (2000), "Highly Crystalline Faujasite Zeolite from Fly Ash", Journal of Hazardous Materials B 77, 123131.

[17] Rayalu, S. S., Udhoji, J. S., Munshi, K. N., dan Hasan, M. Z., (2001), "High Crystalline Zeolite A from Fly Ash of Bituminous and Lignite Coal Combustion", Journal of Hazardous Materials B $88,107-121$.

[18] Somerset, V., Petrik, L., dan Iwuoha, E., (2007), "Alkaline Hydrothermal Conversion of Fly Ash Precipitates Into Zeolite: The Removal of Mercury and Lead Ions from Waste Water", Journal of Environment Management 01, 1-7.

[19] Sudarno, (2008), "Pengaruh Komposisi $\mathrm{NaOH}$ pada Konversi Abu Layang Batubara Paiton menjadi Zeolit A", Tugas Akhir Kimia-FMIPA ITS, Surabaya, hlm. 23-25.

[20] Tomasz, T. W., Fumio, S., Qiwu, Z., (2008), “The Effect of Low Solid/Liquid Ratio on Hydrothermal Synthesis of Zeolites from Fly Ash", Fuel 87, 3194-3199.

[21] Zhdadof, S. P., (1971), "In Advance in Chemistry Series 101", ACS, Washington DC, 20-43. 